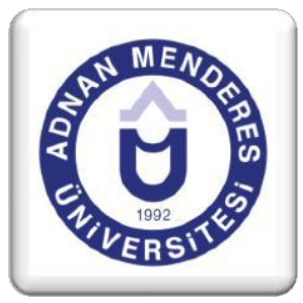

\title{
Hazar Havzası'nda Enerji Güvenliği ve Enerji Jeopolitiği
}

\author{
Muhammed Emin KOCAMAN ${ }^{1}$
}

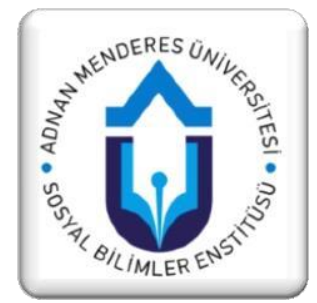

\section{ÖZET}

Hazar Havzası sahip olduğu petrol ve doğalgaz kaynakları ile küresel ve bölgesel güçlerin ilgisini çeken jeostratejik ve jeoekonomik bir öneme sahiptir. Bölgede etkili olmaya çalışan küresel aktörler, enerji kaynaklarının çıkarılmasını, dünya piyasalarına ulaştırılmasını ve enerjiyi kontrol etmeyi istemektedir. Hazar, sadece Rusya ve İran kontrolündeyken, SSCB'nin dağılmasıyla beş devletin ortak kullanımına açılmış ve Hazar'da güç mücadeleleri başlamıştır. Günümüzde halen devam eden Hazar'ın statüsünün belirlenememesi bu bölgede var olan enerjiye yeterli bir şekilde ulaşılamamasına ve istenilen şekilde uluslararası pazarlara transferinin sağlanamamasına neden olmaktadır. Hukuki boşluğun yanı sıra bölgede süren çatışma ve ayrılıkçı hareketlenmeler bölgedeki enerjinin ve nakil hatlarının güvenliğini olumsuz etkilemektedir. Bu sorunlara uluslararası aktörlerin kendi emelleri doğrultusunda izlediği dış politikalar da eklendiğinde Hazar Havzası karışıklıklar ve çözülmeyen sorunlar içinde kalmıştır. Bu makalede özellikle Hazar'da bulunan enerji ile birlikte enerji güvenliği üzerinde söz sahibi olmak isteyen bölgesel ve küresel aktörlerin yaklaşımları ile izledikleri politikalar incelenmiş, enerji güvenliğinin, bölgesel barışın ve istikrarın nasıl sağlanabileceği gibi temel sorunların çözümü için çalış1lmıştır.

Anahtar Kelimeler: Hazar Havzası, Enerji, Enerji Güvenliği.

\section{Energy Security and Energy Geopolitics in the Caspian Basin}

\begin{abstract}
The Caspian Basin has a geostrategic and geoeconomic importance that attracts global and regional powers with its oil and natural gas resources. Global actors who are trying to be effective in the region, want to take out the energy resources, reach the world markets and control the energy. The Caspian was once only under control of Russia and Iran, but with the disintegration of the USSR, the Caspian became a communal area of five states, and the conflicts in the area has started. Today, the inability to determine the Caspian Basin's status, causes the existing energy in this region to be inadequately attained and transferred to international markets in the desired manner. Besides the legal gap, the conflicts and separatist movements in the region, affect the security of the energy and transmission lines in the region negatively. When we add the foreign policies of the other countries which they implement according to their national interest, the Caspian Basin remained with unresolved problems and confusion. This article will, especially, analyse the approaches and the policies of the global and regional powers which want to have a say in the issue of the Caspian energy and energy security. With this article work on how to solve basic problems such as energy security regional peace and stability.
\end{abstract}

Keywords: The Caspian Basin, Energy, Energy Security.

\footnotetext{
${ }^{1}$ Uluslararası İlişkiler Uzmanı, eminkocaman29@gmail.com
} 


\section{Giriş}

Hazar Havzası sahip olduğu jeopolitik, jeostratejik konum ve doğal kaynaklar bakımından oldukça büyük bir önem taşımakla birlikte aynı zamanda enerji kaynakları bakımından dünyada ikinci sırada yer almaktadır. Sahip olduğu enerji kaynakları sayesinde hem kıyıdaş ülkelerin hem de diğer ülkelerin dikkatini üzerine çekmiş̧tir. Sovyet Sosyalist Cumhuriyetler Birliği'nin dağılması ile Azerbaycan, Türkmenistan ve Kazakistan zengin petrol ve doğalgaz yataklarını egemen devlet olarak işletme hakkı kazanmışlardır. Bununla birlikte bu kaynakların işletilmesi için Batılı şirketler ile anlaşmalar imzalanmıştır. Bu anlaşmalar Batının bölgeye girmesine ön ayak olmuştur. Bunun üzerine özellikle bölgedeki hâkimiyetini korumak isteyen Rusya, hem ekonomik gücünü arttırmak hem de bölgedeki etkinliğini korumak istemektedir.

Enerji kavramı, başlı başına uluslararası sistem içinde gündemi belirleyen bir özelliğe sahiptir. Enerji politikalarının önceliği ve enerji sorunlarından kaynaklanan tehditlerin kesişme noktasında bulunan enerji güvenliği yaklaşımı, sürekli bir değişim ve gelişim içindedir. Devletlerin ekonomik açıdan gelişmelerinin sağlanması ve devamlılığın korunması büyük oranda enerjiye bağlıdır. Bu kapsamda gelişmişlik; enerjinin zamanında, yeterli, kaliteli, ekonomik ve güvenilir bir şekilde temin edilmesiyle alakalıdır. Ancak giderek artan enerji ihtiyacına karşılık enerji rezervlerinin sınırlı olması hem enerjinin önemini arttırmakta hem de var olan enerjinin güvenliğinin sağlanması noktasına dikkat çekmektedir. Bu yüzden enerji güvenliği, ulusal ve uluslararası güvenliğin ayrılmaz bir parçasıdır.

Soğuk Savaş sonrası dönemde Hazar, dünya güç mücadelelerinin yaşandığı bir bölge haline gelmiştir. Sahip olduğu enerji kaynaklarının yanı sıra Doğu-Batı arasındaki enerji transfer noktası olma özelliği taşımaktadır. Bu da hem bölge içi hem de bölge dışı aktörlerin müdahalelerine neden olmaktadır. Bölgedeki enerji koridorunu kontrol etmek, bölgedeki enerjiyi kontrol etmek anlamına geldiği için bütün aktörler, bölgedeki boru hatlarının kontrolünü ele geçirmek için oldukça çaba harcamaktadır.

Bölge ülkelerinin denize çıkışı olmadığından dolayı buradaki petrol ve doğalgaz taşımacılığında en önemli unsur boru hatları olmuştur. Sovyetler Birliği zamanında yapılan bütün boru hatları Rusya merkezli olduğundan dolayı, Soğuk Savaş sonrası enerji taşımacılığı Rusya kontrollü gerçekleşmektedir. Rusya'nın bu hâkim gücünü kırmak isteyen Batı, yeni alternatif boru hatları projeleriyle enerji ulaşımına devam etmek istemektedir. Burada önemli olan konu ise var olan enerjinin kontrolünün ve güvenliğinin yanı sıra yapılan ve yapılması planlanan boru hatlarının da güvenliğinin sağlanmasıdır. Ancak bölgedeki devletlerin Hazar' daki pay dağılımındaki anlaşmazlıkları, bölgedeki etnik ve ayrılıkçı hareketlenmeler ve küresel aktörlerin kendi çıkarları için desteklediği problemler bu bölgenin ve enerjinin güvenliğini tehlikeye atan unsurlardır.

Çalışmada, bölgede yaşanan krizlerin temelinde Hazar'ın sahip olduğu stratejik önemin yanında, bulunan rezervlerin küresel anlamda ekonomiyi etkileyebilme kapasitesi nedeniyle, hem bölgesel hem de küresel güçlerin bu rezervleri kontrol altına alarak ekonomik çıkar elde etmek istemeleri varsayılmıştır. Bu bilgiler ışığında Hazar Havzası'nda enerji güvenliğinin, bölgesel barışın ve istikrarın nasıl sağlanabileceği gibi temel sorunların çözümü için çalışılmıştır.

\section{Güvenlik ve Enerji}

Enerji güvenliği konusu üzerine çalışanların ortak düşüncesi ilk olarak, enerji güvenliği kavramının tanımlanmasının çok zor olduğudur. Enerji güvenliğinin klasik tanımını yapacak olursak, ülkelerin petrol ihtiyaçlarını karşılayabilmek için kaynaklara ulaşabilmeleri 
bağlamında arz güvenliğinin sağlanmasıyla sınırlandırılabilir. $\mathrm{Bu}$ bakış açısı enerji güvenliğinin unsurlarını petrol arzı, talep merkezleri, jeopolitik ve piyasa yapıları olarak tanımlamaktadır (Çelikpala, 2014).

Enerji güvenliği bünyesinde yer alan enerji kaynaklarının güvenilir, ucuz ve kesintisiz bir şekilde sağlanabilmesi ve verimli kullanılabilmesi bütün devletlerin ulusal güvenliğini temelden etkileyen bir faktördür (Y1lmaz, 2009). Bu nedenle günümüzde hem uluslararas1 hem de ulusal ortamlarda üzerinde konuşulan konuların başında enerji güvenliği gelmektedir. Enerji güvenliği kavramı, enerji üretim, iletim ve dağıtım sistemlerinin alt yapısına yönelik olası terör saldırılarından, yatırım eksikliklerinin doğuracağı kesintilere, ambargolara, grevlere, iç savaştan işgale kadar birçok olasılığın birlikte değerlendirilmesini gerekli kılan bir kavramdır.

Enerjinin ekonomik güç kazanması tarihsel süreç içerisinde gerçekleşmiştir. Enerjinin aynı zamanda jeoekonomik güç olması nedeniyle enerji ve enerji güvenliği ile jeopolitik teoriler arasında bir ilişki mevcuttur. Bu jeopolitik teoriler Mackinder'in "kara hâkimiyet teorisi", Mahan'ın "deniz hâkimiyet teorisi”, Spykman'ın "kenar kuşak teorisi” ve Scitaklian'ın "hava hâkimiyet teorisi" dâhil olmak üzere bütün jeopolitik teorilerin enerji güvenliği ile doğrudan bağlantısı vardır. Çünkü enerji kaynağının çıktığı bölge, enerjinin taşınması sürecindeki güzergâhlar veya bu yollar üzerindeki kritik boğazlar, depolama ve rafine tesisleri gibi yerler konumları açısından devletler için kritik önem taşımaktadır. $\mathrm{Bu}$ özellikleri enerjinin jeopolitik teoriler açısından anlam kazanmasına sebep olmaktadır (Demir, 2015: 146-151).

Modern dönemin enerji güvenliği anlayışını şekillendiren olay 1973 Petrol Krizi'dir. 1960'lı yılların başından 1970'lerin ilk yıllarına uzanan on yıllık dönemde dünya ekonomisi hızla büyümüş, uluslararası ticaret ve buna bağlı olarak enerji ihtiyacı oldukça artmıştır. 1950'li yıllara kadar büyük uluslararası petrol şirketlerince kontrol altında tutulan ticari sistemin değişmesi, millileştirmeler ile küçük çaplı petrol şirketlerinin kurulmasıyla sağlanmıştır. 1950'li yıllara kadar yaşanan uluslararası gelişmeler, petrol üreticisi olan ülkelerin, petrol fiyatlarının belirlenmesi ve kendilerini ilgilendiren konuların tamamında işbirliği içinde faaliyet göstermelerini sağlamak amacıyla 1960 yılında Petrol İhraç Eden Ülkeler Teşkilatı'nı (Organization of Petroleum Exporting Countries - OPEC) kurmuşlardır (Çelikpala, 2014).

Petrolün ilk kez silah olarak kullanılması konusunu gündeme getiren ve enerji güvenliğini şekillendiren olaylar 1967'de İsrail'in Mısır'a saldırması ve Ekim 1973'te yaşanan 4. Arapİsrail savaşlarıdır. Orta Doğu'da iktidara gelen sosyalist ve milliyetçi rejimler başta petrol olmak üzere doğal kaynaklar üzerinde millileştirme girişimlerine başlamışlardır. $\mathrm{Bu}$ hareketlerin Batı karşıtı tutumları ile 1967 Arap-İsrail savaşında yaşananlar, petrol sahibi Arap ülkelerinde, petrolü İsrail'i destekleyen Batıya karşı bir silah olarak kullanabilecekleri düşüncesini doğurmuştur. Bu dönemde petrolün millileştirilmesi ve silah olarak kullanılması düşüncesi enerji güvenliği anlayışının parametrelerini oluşturmuştur (Çelikpala, 2014; Sevim, 2012).

Diğer yandan 1980'li yıllardaki düşük enerji fiyatları enerji güvenliği konusunu uluslararası gündemin dışında bırakmıştır. Soğuk Savaş'ın bitmesi ve küreselleşme ile birlikte yeni pazar alanlarının ortaya çıkması ve bunun piyasaların birleşmesine olumlu yöndeki etkileri bu sürece katk1 sağlamıştır. Enerji, devletler için stratejik ve jeopolitik öncelikler açısından halen başta gelmektedir (Kruyt, 2009). Ancak diğer yandan, belirgin stratejik ve jeopolitik boyutun etkisinde uluslararası gelişmelerin sonucu olarak ortaya çıkan yeni koşullar, enerji güvenliği kavramına rekabetin yanı sıra işbirliği de eklemiş ve yeni bir boyut kazandırmıştır. 
1990'l1 y1llarda yaşanan siyasi, askeri, ekonomik, ticari, çevresel gelişmeler ve doğal afetler enerji güvenliği konusunu daha farklı ve daha kapsamlı bir hale getirmiştir. Yeni dönemle birlikte çeşitlendirme, rekabet ve arz güvenliği halen enerji güvenliğinin önemli unsurları olarak konumlarını korumakla birlikte, son on yılda içerik ve çerçevenin büyük bir şekilde değişmeye başladığı görülmektedir. Bundan dolayı yakın dönemde kesintisiz petrol ihtiyacından doğalgaz dâhil enerji kaynaklarının iletimini sağlayan kritik enerji altyapısının korunmasına, biyoenerji kaynaklarının durumundan, yenilenebilir enerji kaynaklarının geliştirilmesine kadar, ulaşım ve farklı unsurlara öncelik tanıyan tanımlamalara ulaşılmaktadır. $\mathrm{Bu}$ doğrultuda enerji güvenliğinin ekonomik büyüme ve siyasi gücün korunması da dâhil olmak üzere çeşitli unsurları dikkate alan, enerjinin üretilmesi ve taşınmasını sağlayan kritik enerji altyapısının korunmasını da içine alan geniş bir kavrama dönüştüğü söylenebilir (Jansen ve Boots, 2004).

Uluslararası toplumun, yaşanan gelişmeler ve küresel anlamda artan enerji ihtiyacının etkisiyle artan enerji fiyatlarının baskısı altında, enerji güvenliği konusunu gündeme aldığı görülmektedir. Konunun ele alındığ1 ilk uluslararası toplantı 2006'da St. Petersburg'da düzenlenen G-8 zirvesidir. Zirvenin gündem maddesi olarak küresel enerji güvenliği belirlenmiş ve zirvede enerji güvenliğine günümüze uygun bir tanım ve içerik kazandırılmaya çalışılmıştır. Sonuç bildirgesinde ise geçen süre zarfında enerji güvenliğinin yeni koşullara yeterince uymadığı, içinde bulunduğumuz karmaşık dönemdeki ilişkileri açıklamada yetersiz kaldığı ifade edilmiştir. Bildiride en önemli tehdit olarak terör saldırılarının görüldüğüne ve bu konuda enerji altyapısına yönelik saldırılara karşı uluslararası işbirliğine gidilmesi gerektiğine önemle vurgu yapılmıştır (St. Petersburg Bildirisi, 2006). Kısacası, toplantı yeni dönemin enerji güvenliği anlayışının şekillendirilmesi sürecinde bir dönüm noktası olarak önem kazanmıştır.

Enerji güvenliğini günümüzde petrolün kesintisiz akışının sağlanması ve çeşitlendirilmesi olarak tanımlamak yeterli değildir. Enerji güvenliği temelde, enerjinin elde edildiği yani çıkarıldığı bölgeden, makul bir fiyat üzerinden, kesintisiz bir şekilde ve yeterli miktarda alıcı ülkeye ulaştırılmasıdır. Bu çerçevede, boru hatlarının korunmasından, denizlerdeki petrol ve doğalgaz platformlarının korunmasına ve petrol ile doğalgazı taşıyan tankerlerin izledikleri rotaların güvenliğinden, depolama tesislerinin korunmasına kadar geniş bir alanda, çok boyutlu ve kapsamlı bir tanım üzerinde durulmaktadır. Böylece enerji güvenliği konusu tüm boyutlarıyla 21. yüzyılın öncelikli konusu haline gelmiştir (Çelikpala, 2014; Demir, 2015: 146-151).

Yeni enerji jeopolitiğinde ülkelerin askeri gücünden ziyade, enerji açığı ya da fazlalığına göre kategorize edilecekleri ifade edilerek, boru hatlarının öneminin giderek artacağına değinilmiştir. Artan enerji ihtiyacının karşılanması için güç mücadelelerinin yeniden ortaya çıkacağı ve sorunlu bölgelerdeki kaynakların geliştirilmesi zorunluluğu boru hatlarının önemini arttırmıştır. Enerji talebinin artmasından kaynaklanan gelişmeler sonucunda boru hatları güzergâhlarının belirlenmesinde jeopolitik unsurların piyasa mekanizmasından daha etkili olduğu ortaya çıkmıştır (Jansen ve Boots, 2004). Yapılan çalışmalar neticesinde boru hatlarının seçiminde ekonomik kriterlerden ziyade jeopolitik unsurların daha önemli olduğu sonucuna varılmıştır. Enerji güvenliğinde jeopolitiğin önemli bir unsur olmasından dolayı, enerji yatırımlarının ekonomik boyutunun da göz ardı edilmemesi gerekmektedir.

Enerji güvenliği 21. yüzyılda daha boyutlu ve kapsamlı bir hal almıştır. Risklerin çeşitliliği bu yeni boyuta risklerin azaltılması ve risklerle mücadele boyutunu da katarak yeni bir bakış açısı kazandırmıştır. Üretim ve enerjinin kullanımı da dâhil olmak üzere enerjiye olan ihtiyacın azaltılması ve verimliliğin arttırılması konularını gündeme getirmiştir (Kruyt, 2009). Bundan dolay1 yeni enerji güvenliği tanımı enerji akışında oluşan herhangi bir 
aksamayla nasıl mücadele edileceğinden, enerji arz talebinin altyap1 da dâhil olmak üzere nasıl korunacağına kadar geniş bir çerçevede ele alınmaktadır. Bu durum enerji güvenliğine yönelik tehditlerin çeşitlenmesiyle doğru orantılı ve günümüz siyasi, güvenlik ve ekonomik koşullarının yansımasıdır.

\subsection{Hazar Havzası'nda Güvenlik ve Enerji}

Hazar Havzası'nın enerji güvenliğine değinecek olursak, I. Dünya Savaşı'na kadar Orta Doğu petrolleri biliniyor olsa da Sovyet petrolleri ucuzluk ve taşınabilirlik açısından daha elverişli görülmüştür. Sovyetler Birliğ̣i'nin dağılmasından sonra Hazar Havzası'nda en önemli enerji kaynakları Azerbaycan, Türkmenistan ve Kazakistan'a kalmıştır. Bu olay ayrıca diğer dünya devletlerinin bu bölgeye yönelmelerine neden olmuştur (Turan, 2010).

Genel tanımıyla Hazar Havzası; Rusya, Azerbaycan, İran, Türkmenistan ve Kazakistan ile çevrili bir bölgedir. Hazar'a doğrudan kıyısı olmadığı halde, Hazar petrollerinin pazarlanması aşamasında etkilenen Ermenistan, Gürcistan ve Özbekistan'da bu alana dâhil edilebilmektedir. Hazar Havzası'nda bulunan ülkelerin çevresinin, nükleer gücü olan devletler tarafından sarılmış olduğu bir gerçektir. Diğer bir komşu ülke olan Türkiye ise hem NATO üyesi olarak hem de bölge ülkeleriyle karşılıklı sahip olduğu tarihi ve kültürel bağlarla birlikte bu rekabet ortamında kendine yer edinmiştir. Amerika Birleşik Devletleri (ABD)'nin de terörle mücadele kapsamında Afganistan'a girmiş olması bir bakıma ABD'nin komşu ülkeler arasındaki rekabet ortamı içinde yer edinmesine sebep olmuştur.

Hazar Havzası'nın küresel politikalarda anlaşmazlıklara neden olmasındaki en büyük etken, petrol ve doğalgaz rezervlerinin büyük bir bölümünü bulunduruyor olmasıdır. Aynı zamanda Hazar'ın hukuki statüsü konusundaki belirsizlik de bu anlaşmazlıklara neden olmaktadır. Hazar'daki sorun buranın deniz mi göl mü olacağ1 ve hangi uluslararası normlara göre hareket edileceğidir. Aslında bu sorunu meydana çıkaran Rusya'nın asıl amacı, ortalığı karıştırarak çok uluslu petrol şirketlerinin bölgeden çekilmesini ve bu bölge üzerinde tek başına başat güç olmak istemesidir (Brzezinski, 2005: 135). 12 Ağustos 2018 tarihine gelindiğinde kıyıdaş devletler Kazakistan'ın Aktau şehrinde düzenlenen zirvede bir araya gelerek uzun yıllar süren çalışmaların neticesinde Hazar'ın statüsü konusunda bir anlaşmaya varmışlardır. Anlaşmaya göre; Hazar'a kıyısı olan her ülke 15 deniz mili geniş̧liğinde karasularına sahip olacaktır. Karasularının bittiği noktadan itibaren balıkçılık sektörü için bölgeler 10 mil daha uzatılabilecektir. Bu sınırlamanın dışında kalan deniz alanı kıyıdaş devletlerin ortak kullanımına bırakılacaktır. Hazar'a özel statü verilerek 1982 Birleşmiş Milletler Deniz Hukuku Sözleşmesi (BMDHS)'nin dışında tutularak suyun derinliği göl prensiplerine göre belirlenecektir. Hazar Denizi'nin tabanı egemenlik hakları çerçevesinde karışı karşıya ve yan yana olan devletler arasında daha sonra belirlenecektir. Ayrıca Hazar'a kıyısı olmayan devletler burada silahlı kuvvet bulunduramayacaktır. Yapılan bu anlaşma ile birlikte uzun yıllar devam eden statü sorunu ortadan kaldırılmak istenmiş, bölgedeki anlaşmazlıkların giderilmesi ile birlikte kıyıdaş devletlerin ekonomik ve güvenlik açısından yaşadığı problemler ortadan kaldırılmaya çalışılmıştır (Anadolu Ajansı, 2018).

1950 ve 1960'lı yıllarda hızlı ekonomik büyümenin temel taşını petrol oluşturmuştur. Sovyetler Birliği'nin dağılmasıyla birlikte Orta Asya'da petrol mücadeleleri başlamıştır. Bu mücadelede ev sahibi beş Türk Cumhuriyeti, aktörler ise ABD, Çin, Rusya, Türkiye, İran ve Avrupa Birliği (AB)'dir. Hazar Havzası'nın enerji rejiminin belirlenmesinde Azerbaycan, Kazakistan ve Türkmenistan üretici ülke olarak merkezde yer almaktadır. Bu merkezleri çevreleyen aktörler ABD, Çin ve AB, Hazar Havzası'nın petrol ve doğalgazını uluslararası alana taşıma ve bundan pay almaya çalışmaktadır. İran ve Türkiye ise bölgesel aktör olarak hidrokarbon ticaretinden pay almak ve boru hatlarını kontrol etmek amaciyla stratejik bir 
kazanç sağlamak istemektedir. Rusya ise herkesten farklı olarak enerji açısından bölge üzerinde doğrudan hâkimiyet kurmayı planlamaktadır (Birsel, 2006: 78).

Azerbaycan, Türkmenistan ve Kazakistan, Hazar Havzası'nın petrol ve doğalgaz açısından en önemli ülkeleridir. Çünkü Rusya ve İran'ın sahip olduğu hidrokarbon rezervleri oldukça azdır. Azerbaycan, Türkmenistan ve Kazakistan'ın sahip olduğu rezervlere ulaşabilmeleri için teknolojik desteğe ihtiyaçları vardır. Bu desteği sağlayacak unsurlar uluslararası şirketler olduğundan, şirketlerin bu bölgeye yönelimleri artmıştır (Koçgündüz, 2010: 488). Hazar, bir bakıma sahip olduğu hidrokarbon rezervleriyle dünyanın diğer bölgelerine alternatif olmaktadır. Bölgedeki enerji kaynaklarının bulunup çıkartılması ve uluslararası pazarlara ulaştırılması büyük rekabetlerin yaşanmasına ve küresel ve bölgesel aktörlerin karşı karşıya gelmesine neden olmaktadır. Bölge devletleri daha kısa vadeli enerji planlamaları yapsa da, dış aktörler bölgeyi hegemonyaları altına almaya ve enerji kaynaklarında uzun dönemli planlamalar yapmaya çalışmaktadır (Yüce, 2007: 47; Külebi, 2007: 10).

BP Statistical Review of World Energy Haziran 2016 verilerine göre gaz rezervlerinin \%42,5'i Orta Doğu'da, \%28,7'si Avrasya'da bulunmaktadır (BP). Diğer ülkeler bu veriler doğrultusunda Hazar'ın avantajlarından yararlanıp, bu bölgede hâkim güç olmak istemektedir. Orta Doğu'daki istikrarsızlık ve çatışma ortamı ister istemez ilgiyi bu yöne yani Hazar'a çevirmektedir. Aynı zamanda bölgedeki enerji kaynakları, Orta Doğu merkezli fiyat krizlerinin yaşanmaması için bir önlem niteliği taşımaktadır. Ayrıca bu bölge RusyaÇin gibi iki dünya devi ile batı ekonomileri ve gittikçe büyüyen doğu ekonomileri arasında bir köprü konumundadır. İlerleyen zamanlarda Batı'nın elinde bulunan Kuzey Denizi enerji kaynaklarının tükenecek olmasından dolayı, Hazar Havzası, Kuzey Denizi'nin yerini almaya aday gösterilmektedir (Nogayeva, 2007). Hazar enerji kaynaklarının önemini gösteren asıl nokta ise, başlıca talep merkezlerinin ilerleyen 20 yılda ithal petrole bağımlılık oranlarında belirgin bir artış olması ve enerji arz güvenliğini sağlayacak alternatif bölgeler arasında yer almasidir (Pala, 2003).

Şekil 1: 2016 yılı dünya ispatlanmış doğalgaz rezervleri dağılımı (Kaynak: BP)

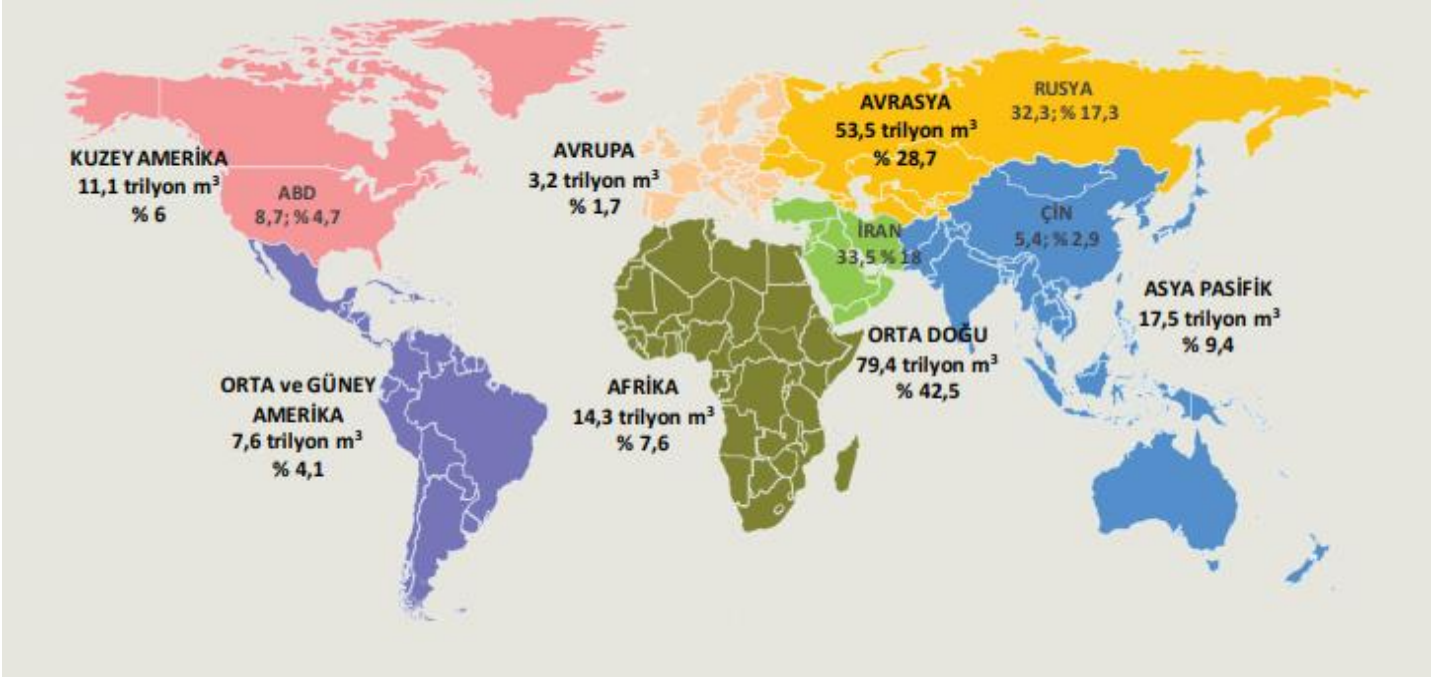


Şekil 2: 2022 yılı petrol açık ve fazlası olması öngörülen bölgeler (Kaynak: IEA Oil 2017)

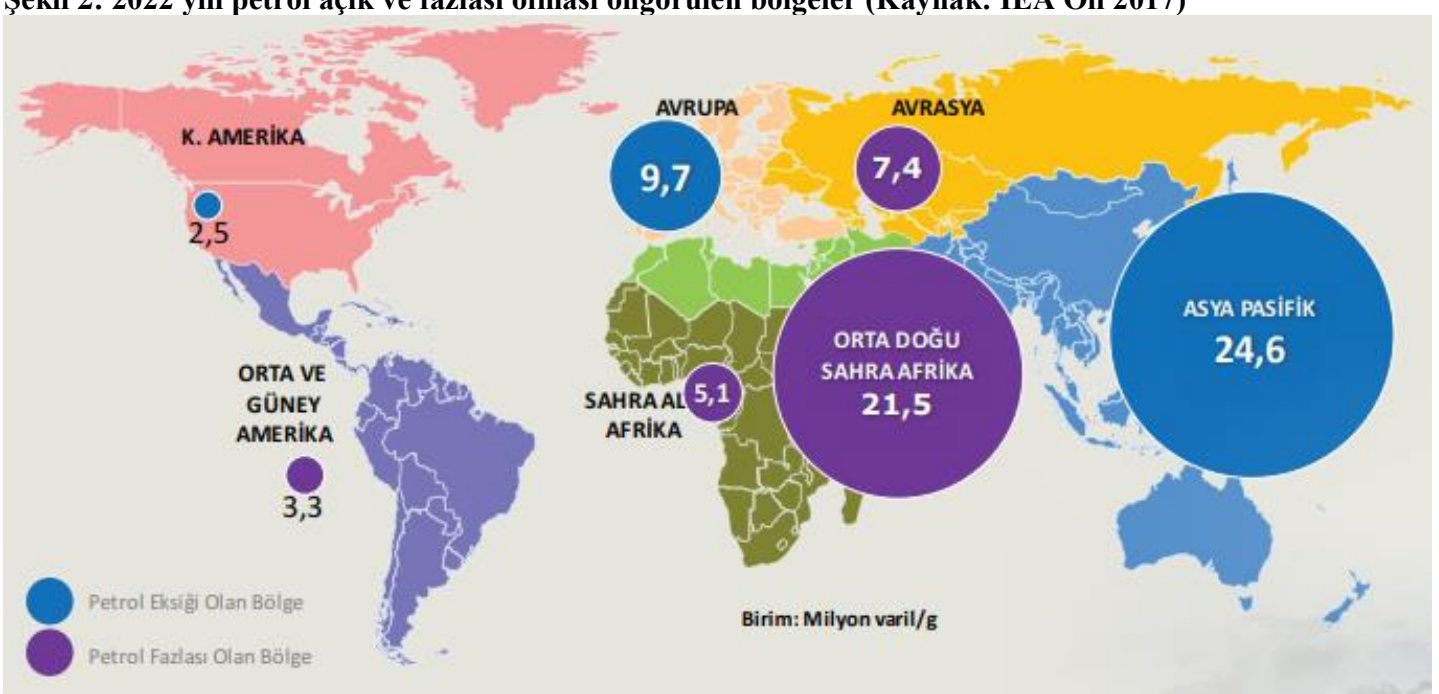

Hazar Havzası'nda petrol ve doğalgazın taşınması da başlı başına bir sorundur. Sovyetler Birliği zamanında inşa edilen boru hatlarına alternatif güzergâhlar konusunda 1991'den sonra çalışmaların hızlandığı görülmektedir. Günümüzde bu kaynakların ulaşımda kullandıkları hatlar tamamen Rusya'nın taşımacılık sistemine bağlıdır. Hazar ile Karadeniz'i birbirine bağlayan ve Rusya'nın kontrolünde olan iki boru hattı bulunmaktadır. Kuzey hat, Hazar petrollerini Grozni'den Novorossisk'e taşımaktadır. Güney hat ise petrolü Gürcistan'1 içine alan doğu-batı eksenini aşarak Batum üzerinden Karadeniz'e ulaştırmaktadır (Meulen, 2009).

Petrol ve doğalgaz gibi enerji kaynaklarının çıkarıldığı yerden, işleneceği ve tüketileceği merkezlere ulaşımında tercih edilen ilk yol boru hatlarıdır. Boru hattı taşımacılığı uzmanlara göre en güvenli ve en ekonomik yoldur. Bu enerji kaynakları sadece ticareti yapılan mallar değil, bulundukları bölgelerin kontrolünü sağlayan devletler açısından stratejik önem taşımaktadır. $\mathrm{Bu}$ durum doğal kaynaklardan dolayı stratejik rekabetlerin yaşandığı Avrasya'nın kalbinde yer alan Hazar Havzası incelendiğinde açık bir şekilde görülmektedir (Oğan, 2007).

Hazar kaynaklarıyla ilgilenen Batılı devletler açısından en önemli unsurlardan biri, açık denize kapalı sahalarda bulunan enerji kaynaklarını büyük piyasalara taşıyacak makul fiyat ve güvenilir boru hattı sisteminin oluşturulmasıdır. Söz konusu sistemin yapılabilmesi hem büyük maliyetli olup hem de bölgenin karmaşık jeopolitiği nedeniyle oldukça güç bir meseledir. İnşa edilecek her türlü boru hattı en çok zararı petrol fiyatlarının yüksek kalması için çaba harcayan OPEC üyelerine verecektir. Bu nedenle Hazar'dan gelecek ek petrolün dünya petrol fiyatları üzerinde önemli bir etki unsuru oluşturacağı kaçınılmazdır (Pala, 2007).

Hazar Havzası'nı kapsayan politikalar, diğer rekabet ortamlarından farklılık göstermektedir. Rusya'nın enerjiyi dış politikada siyasi bir araç olarak kullanmaya başlaması ile birlikte Hazar'ı arka bahçesi olarak görmesi ve SSCB döneminden kalan bağları kullanması bir bakıma onu bu mücadelede avantajlı konuma getirmektedir (Meulen, 2009). Bölgeyle 
kültürel geçmişe sahip olan Rusya ve Türkiye'nin, boşluğundan yararlanmak isteyen İran'ın enerji alanındaki rekabeti ise bölgeyi daha da özgün bir konuma getirmektir. ABD kontrolündeki şirketlerin bölge ekonomisine müdahil olmasıyla beraber ABD’yi, küresel güç olma yolunda ilerleyen Rusya ve Çin'e karşı da önlemler almaya itmiştir. Enerji arz güvenliğini teminat altına almaya çalışan ve OPEC ile Rusya tekelinden kurtulmak isteyen ülkeler, Hazar'a yönelmektedir (Koçgündüz, 2010: 499).

Bugün Hazar Havzası'nda yaşanan mücadele, enerji merkezli bir denge oyunu olduğundan gelecekte bu bölge önemli bir nitelik taşıyacaktır. Enerji olmadan ekonomiden ve ekonomik faaliyetlerden söz etmek mümkün değildir. 21. yüzyılda enerjiye sahip olmak aynı zamanda güce de sahip olmak anlamına gelmektedir (Kasım, 2006: 243). Bu kapsamda ülkelerin dış politikalarının vazgeçilmez bir unsuru olan enerji kaynakları, teorik açıdan realist bir bakış açısıyla incelenmelidir. Güce ulaşabilmek için diğer devletlere üstünlük sağlamak gerekmektedir. Realist teorinin vurguladığı güvenlik ikilemi bütün şekliyle Kafkasya'da görülmektedir. Devletlerarasındaki ilişkilerde bir tarafın kazancının öteki tarafın kaybı olarak nitelendirilmesi, bloklaşmanın ortaya çıkması ve devletlerin ulusal yapılarından dolayı çıkan sorunlar Kafkasya'yı çatışma bölgesi haline getirmiştir.

Kısaca özetlememiz gerekirse, dünya enerji talebini büyük ölçüde karşılayan Orta Doğu'daki istikrarsızlık, eleştirel İran dış politikası, petrol fiyatlarındaki dengesizlik, Rusya'nın sahip olduğu enerji gücü, enerji tüketen ülkeleri oldukça rahatsız etmektedir. Bu nedenle bir yandan enerji kaynaklarına alternatif bulmak ve kaynakları arttırmak isteyen enerjiye bağımlı ülkeler ile bu alanda yatırım yapmak isteyen uluslararası şirketler, Hazar Havzası'na yönelmişlerdir. Terör anlamında Orta Doğu'dan daha güvenli olan Hazar'ın enerji arz güvenliğini sağlaması, Rusya'nın enerji tekelini kırma, bölgenin Çin, Rusya ve Orta Doğu arasında yer alması sonucunda stratejik bir konumda bulunması Hazar'ın önemini arttırmaktadır.

\section{Bölge Ülkelerinde İstikrar Sorunu}

Orta Asya ve Kafkasya'da petrol ve doğalgaz ihraç eden ülkelerde istikrar devam ettikçe enerjiye ihtiyaç duyan ülkelerin enerji trafiği sürekli olarak devam edecektir. İstikrar ortamı korunarak Hazar'da bulunan enerji Türkiye üzerinden, Rusya'ya bağlı olmadan Avrupa'ya ihraç edilebilecektir. Böylece hem Rusya'nın enerji üzerinde tekel olması engellenecek hem de bu enerji trafiğinin sağlanmasında aracı olan başta Türkiye olmak üzere diğer ülkelerde maddi gelir elde edebileceklerdir. Fakat Türkiye'nin komşusu olan Orta Asya ve Kafkaslarda tam bir istikrar ortamının sağlanabildiği söylenemez. SSCB'nin tamamen dağılması ve bununla beraber ortaya yeni bağımsız devletlerin çıkması da birçok sorunu beraberinde getirmiştir (Devlet, 2006: 97).

Kafkasya'daki Sorunlar: Kafkasya, bölgesel çatışmalarla sürekli dünya gündemine gelen bir bölgedir. Kuzey Kafkasya, Rusya Federasyonu'na dâhil olan altı özerk cumhuriyetten oluşmaktadır. Çeçenistan'ın konumu Doğu Kafkasya ile Batı Kafkasya arasında bağlantıyı sağlayan stratejik bir önem taşımaktadır. Çeçenistan'dan, karayolları ve demiryollarının yanı sıra enerji boru hatları da geçmektedir. Bütün yolların kesişiminde bulunan Çeçenistan, özelde Rusya için, petrol ve doğalgaz boru hatlarının geçmesi nedeniyle genelde dünya için büyük bir önem taşımaktadır (Tanrısever, 2001). Burada yaşanan çatışmalar ve boru hatlarına karşı yapılan olumsuz müdahaleler enerji güvenliğini de tehlikeye atmaktadır. $\mathrm{Bu}$ çatışmalar ve sabotajlar sonucunda yaşanan enerji kesintileri ithalatçı ülkeler açısından önemli sorunlara neden olmaktadır.

Dağıstan, Rusya Federasyonu içinde diğer bir sorunlu bölgedir. Etnik yap1 açısından Kafkasya'nın en karışık bölgesidir. Otuzdan fazla etnik grup bulunmaktadır. Doğalgaz 
zengini olmasına rağmen ekonomik yönden oldukça kötü bir durumdadır ve Rusya'nın yardımlarıyla ayakta durmaktadır. Dağıstan'da sıcak bir çatışma yoktur. Hazar'a kıyısı olmasından dolayı Dağıstan'ın konumu daha da stratejik bir önem arz etmektedir. Var olan enerji kaynaklarının Avrupa'ya taşınması konusunda Kafkasya bölgesinin önemi daha da artmıştır. Bu bölgenin sahip olduğu çatışma potansiyeli enerji güvenliği açısından önemli riskleri de beraberinde getirmektedir (Kantarc1, 2006: 160).

Dağlık Karabağ sorunu ise Kafkaslarda halen güncelliğini koruyan çok önemli bir konudur. Karabağ'da yaşanan Azeri-Ermeni çatışması oldukça köklü bir geçmişe dayanmaktadır (Gündüzhev, 2013). Dağl1k Karabağ sorunu başladığı tarihten günümüze kadar halen devam etmektedir ve hatta Nisan 2016'da tekrardan sıcak çatışmalar yaşanmıştır. Sorunların diplomatik yollarla çözülememesi her iki ülkede aşırı radikal grupların güçlenmesine neden olmaktadır. Çatışma, istikrarsızlık ve göçmen sorunlarından kaynaklı problemler bölgede ekonomik, siyasi ve sosyal açıdan bütün hayatı olumsuz etkilemektedir.

Kafkasya'da yaşanan önemli çatışmalardan biri de Abhaz-Gürcü çatışmasıdır. SSCB döneminde duran çatışmanın tekrar başlaması SSCB'nin son dönemine denk gelmektedir. 1994 yılında Abhazya ile Gürcistan arasında ateşkes sağlanmıştır. Ağustos 2008'de Gürcü askerlerin Güney Osetya'ya girmesi sonucunda Rusya, 26 Ağustos 2008'de Abhazya ve Güney Osetya'yı bağımsız bir devlet olarak tanımlamıştır. Uzun zaman devam eden GürcüAbhaz anlaşmazlığının nedeni, Abhazya'nın statü sorunundan kaynaklanmaktadır. Abhazlar tam bağımsızlık isterken, Gürcistan toprak bütünlügünü korumak istemektedir. Abhazya Özerk Cumhuriyeti halen de facto olarak bağımsız bir devlet gibi davranmakta ve Rusya'nın dışında birkaç Latin Amerika ülkesi tarafından bağımsız kabul edilmektedir. Fakat hukuki olarak halen bağımsız bir devlet statüsüne sahip değildir (Cicioğlu vd, 2012: 450). Güney Osetya sorununa değinecek olursak, Osetya coğrafyası, Çarlık döneminde olduğu gibi SSCB döneminde de siyasi olarak bölünmüşlük içindeydi. Bir bölümü Güney Osetya Özerk Bölgesi adıyla 1922 yılında Gürcistan'a, diğer bölümü de Kuzey Osetya Bölgesi adıyla 1925 y1lında Sovyetlere bağlanmıştır. 1936 yılında Kuzey Osetya, özerk cumhuriyet statüsü kazanmıştır. SSCB dağıldıktan sonra Kuzey Osetya, Rusya Federasyonu içinde federe cumhuriyet olarak kalırken, Güney Osetya, Gürcistan topraklarına dâhil edilmiştir (Mert, 2004: 60). Gürcistan Enerji kaynaklarında Rusya'ya bağımlı olan Batılı devletler için önemli bir konumdadır. Orta Asya ve Hazar petrollerini uluslararası pazara çıkmasında Rusya'ya alternatif bir güzergâh oluşturmaktadır. Enerji kaynaklarındaki üstünlüğünü kaybetmekten korkan Rusya, bundan dolayı Gürcistan'daki çatışma ve iç karışıklıkları desteklemektedir. Enerji güvenliğini sağlayamayan istikrarsız bir Gürcistan'ın Batı için çekiciliğinin azalacağı düşünülmektedir (Gündüzhev, 2013).

İran Sorunu: İsrail, ABD ve diğer ülke istihbaratlarının İran'ın biyolojik, kimyasal kitle imha silahlarına sahip olduğu ve nükleer silahlar için programlar geliştirdiği hakkındaki ifadeler bütün dünyayı tedirgin etmiştir. 2006 yılında Tahran'ın uranyum zenginleştirmede başarılı olduğunu bildirmesi bu konudaki varsayımları da destekler niteliktedir. İran'ın nükleer silah üretme olasılığı üzerine ABD ile İran arasında çıkan tartışma tehlikeli boyutlara gelmiştir. Bütün dünyayı meşgul etmeye başlayan bu kriz 13 Mayıs 2006'da Bali'de gerçekleştirilen D-8 (Gelişmekte Olan Müslüman Devletler) ülkelerinin 5. Zirvesi sonuç bildirgesinde yer almış fakat üyelerin, alternatif ve yenilenebilir enerji kaynakları ile barışçıl amaçlı nükleer enerji geliştirmeye kararlı İran'ın Dünya Ticaret Örgütü üyeliğine tam destek veriyoruz, demesinden ileri geçememiştir. D-8 ülkeleri arasında sadece Pakistan'ın nükleer silahı bulunmaktadır. Bu zirvede İran'a doğrudan doğruya destek vermeye kimse cesaret edememiştir. İran'a karşı uygulanan ambargolar da İran'ın nükleer çalışmalarının durdurması için yeterli olmamıştır. ABD'nin ve Batının baskıları sonucunda 2015 yılında 
BM güvenlik konseyi daimi üyeleri ve Almanya'nın da katıldığg İran'la 5+1 İran nükleer görüşmeleri gerçekleştirilmiştir. Bu görüşmeler neticesinde İran, Uluslararası Atom Enerji Kurumu tarafından denetlenmeyi ve bazı sınırlamaların getirilmesini kabul etmiştir. Böylece hem Avrupa kontrollü nükleer çalışmalar devam edecek hem de uygulanan ambargonun hafifletilmesine olanak verilecektir (Ünal, 2015).

Orta Asya'daki Sorunlar: Orta Asya'da mevcut beş bağımsız devletin ekonomik, sosyal ve siyasi alandaki ortak sorunlarının yanı sıra kendi coğrafi şartlarından kaynaklanan sorunları da bulunmaktadır. Boru hatlarının geçeceği güzergâh üzerinde bulunmalarından dolayı bu sorunlar ayrı bir önem taşımaktadır.

Kazakistan, son yıllarda artan petrol gelirleriyle birlikte ekonomisinde büyük ilerleme kaydetmiş olsa da güvenliği hayli hassas dengeler üzerinde durmaktadır. Kazak hükümeti, ülkedeki Kazak ve Rus milliyetçilerinin baskıları karşısında kalıcı dengeyi sağlamakta oldukça zorlanmaktadır. Kuzeydeki Rus faktörü hem iç hem de dış politikanın önemli bir unsurunu oluşturmaktadır. Kazakistan'ın diğer bir zayıf noktası ise çok geniş bir coğrafyaya sahip olmasına rağmen nüfusunun az olmasıdır.

Türkmenistan dünyada üçüncü büyük doğalgaz rezervlerine ve önemli petrol yataklarına sahip bir ülkedir. ABD'nin İran'a uyguladığı ambargodan dolayı gazının çoğunu Rusya Federasyonu'na satmaktadır. Ancak Aşkabat doğalgaz alanında Rusya'nın süper güç olmasına destek veren ülke rolü ile anılmaktan oldukça rahatsızdır. Doğalgazla birlikte gelen zenginlik Türkmen halkını rahatlamaya yetse de asıl önemli ikinci konu bu bölgeye has olan su sorunudur. Türkmenistan su ihtiyacını Amuderya'dan bağlanan 1000 kilometre uzunluğundaki Kara-Kum Kanalı ile sağlamaktadır. Ancak bu nehir Özbekistan'ın kullandığı kaynak olduğundan dolayı gelecekte kullanım hakları üzerinde iki ülke arasında kriz çıkma ihtimali oldukça yüksektir. Ayrıca sınıra yakın bir bölgede bulunan Özbek azınlık zaman zaman Türkmenistan ile Özbekistan arasında gerginliklerin yaşanmasına neden olmaktadır (Devlet, 2006: 101-103).

Özbekistan, bölgenin nüfus bakımından en kalabalık ülkesi olması ve iyi yönetilmemesi nedeniyle istikrarsılılı̆a meyillidir. Toplum ve devlette rüşvetin çok yaygınlaşması, yerel siyasi ekiplerin merkezi otoriteyi zayıflatması, Fergana Vadisi ile köylerden Taşkent'in yoksul yerlerine göç eden fakir halk arasındaki radikal İslami hareketlerin görülmesi ve gittikçe artan uyuşturucu trafiği bu ülkenin iç tehditlerini oluşturmaktadır.

Kırgızistan da Kazakistan gibi demografik kayıplar vermiş bir ülkedir. Rus nüfusunun neredeyse $1 / 3$ 'ü ülkeyi terk etmiştir. Diğer sorunu ise komşularıyla olan su sorunudur. Ayrıca Özbekistan ve Çin ile sınır sorunları bulunmaktadır. Tacikistan'dan ülkeye giren İslami militanlar da ayrı bir sorun oluşturmaktadır. 2005 yılında devlet başkanının görevden alınması sonrasında istikrar tekrar sağlanamamıştır. Kırgızistan ülke güvenliğini Şangay İşbirliği Örgütü’ne bağlamıştır.

Tacikistan, Orta Asya'nın en sorunlu ülkesidir. İç savaş büyük can kayıplarının yaşanmasına neden olmuştur. Duşanbe, ülkenin kuzeyinde yoğun Özbek nüfusunun Özbekistan'in desteği ile Sovyet döneminde olduğu gibi siyasi ve ekonomik gücü ele geçirmesinden endişelenmektedir. İkinci tehdit unsuru Afganistan'ın kuzeyindeki Taliban'dır. Üçüncü tehdit ise Afganistan kanalı ile gerçekleşen uyuşturucu trafiği ve bu trafiğe katılan Özbek İslam Hareketi militanlarının ülkeye sızmasıdır.

Afganistan'da iç savaş halen sürmektedir. ABD askeri ülkenin kuzeyindeki Taliban güçleri ile mücadele etmektedir. NATO güçleri ise başkent Kabil ve çevresinin güvenliği için 
çalışmaktadır. Halkın ana geçim kaynağı halen afyon üretimine dayanmaktadır (Devlet, 2006: 103-105).

Kafkasya, Orta Asya ve Hazar Havzası'na barışı getirmek, barışı kalıcı kılmak daha önce bahsettiğimiz sorunların ortadan kaldırılmasıyla sağlanacaktır. Ancak bu sorunları çözmek için gerekli olan iyi niyet ve uzlaşma, bölgenin çeşitli etnik unsurları ile bu bölgeyi siyasi, ekonomik ve askeri yönden etkileyen veya bu bölgeden kazanç sağlayan diğer ülkelerde pek görülmemektedir. Bütün bu sorunların çözülememesinden dolayı Hazar Havzası, enerji ve boru hatları güzergâhlarının güvenliği sürekli tehdit altındadır. Bölgesel ve küresel aktörlerin kazan kazan politikası çerçevesinde hep birlikte bu sorunlara çözüm bulması gerekmektedir.

\section{Küresel ve Bölgesel Aktörlerin Hazar Havzası'na Yönelik Politikaları}

ABD enerji ihtiyacının \%40'ını petrol ile karşılamaktadır. Bu ihtiyacın önemli bir bölümü İran Körfezinden sağlanmaktadır. İlerleyen zamanlarda petrol tüketimindeki artışın yeni kaynakları aramayı ve bu kaynaklar üzerinde etkili olma amacıyla politikalar geliştirilmesini zorunlu hale getirmiştir. Bu politikalar çerçevesinde $\mathrm{ABD}$, uluslararası pazarda petrol ve doğalgaz yataklarının işletilmesi ve geliştirilmesine katılmak isteyen Amerikan şirketlerini desteklemektedir (Gürpınar ve Kesici, 2005).

ABD'nin bölgedeki en önemli stratejik hedefi bölgenin tek bir gücün himayesi altına girmesini engellemektir. Fakat bu amacını gerçekleştirme yolunda ABD'nin önünde $A B$, Çin ve Rusya gibi engeller bulunmaktadır. Bu unsurlar tek başına etkili olmaya yetmese de ikisi veya üçünün bir araya gelmesi ABD için önemli bir tehdit unsuru oluşturacaktır (Nogayeva, 2011). İlerleyen zamanlarda Şangay İşbirliği Örgütünün ortaya çıkması, Avrupa Birliğinin giderek daha bağımsız bir savunma kimliği oluşturması, Rusya'nın nükleer gücü ve Çin'in hızla gelişen ekonomisi ABD'nin bu bölgede güç merkezli bir savaşa girmeden varlığını sürdürmesini zorunlu kılmaktadır (Efegil, 2000).

$\mathrm{ABD}$, Sir Halford Mackinder'in Kara Hâkimiyet teorisinde bahsettiği "Doğu Avrupa'y1 denetleyen aynı zamanda dünya adasına da hâkim olur, dünya adasına hâkim olan, dünyayı da kontrol eder" düşüncesinden yola çıkarak Avrasya'ya hâkim olmak ve dünya devleti konumunu sürdürmek istemektedir. $\mathrm{ABD}$, dış politikası çerçevesinde önemli enerji kaynaklarının bulunduğu bölgeleri, ulaşım yollarını, kritik boğaz ve geçitleri kontrol altına almak istemektedir. Bundan dolayı Hazar Havzası'nın stratejik önemi ve güvenliğiyle yakından ilgilenmektedir (Bilgici, 2005). ABD, bu bölgeye müdahil olabilmek için Rusya ve İran dışında kalan aktörler arasında Türkiye ile işbirliği içine girmiş ve Türkiye güzergâhını kullanarak kendi üstünlügünü pekiştirmek istemektedir. Enerji kaynaklarının güvenli bir şekilde Batıya aktarılmasında Türkiye, Gürcistan ve Azerbaycan güzergâhının kullanılması gerektiğini savunmaktadır. Ayrıca ABD, politikalarını uygulayabilmek için yeri geldiğinde bölgedeki sorunları kendi lehine kullanmayı da bilmiştir (Dedeoğlu, 2003). Küresel bir güç olan ABD, var olan şartlar doğrultusunda Hazar Havzası'nda bölgesel güçlerin etkisine son verememiştir. Ayrıca ABD bölgede istikrar politikaları için reformlar yaptığını söylese de Çin ve Rusya dışındaki bölgesel güçlerin çıkarları doğrultusunda projeler üretememiştir (Somuncuoğlu, 2006).

Çin'in bölgeye olan ilgisi sınır komşusu olmasıyla yakından ilgilidir. Türkistan'ın bir kısmına hâkim olan Çin diğer kısmı, yani Orta Asya ile de ilgilenmek zorundadır (Soligo ve Jaffe, 1999). Ayrıca Orta Asya, Çin'in Avrupa'ya açılan kapısı niteliği taşımaktadır (Telatar, 2005: 178). Çin 21. yüzyılda kısa, orta ve uzun vadede üç büyük strateji gerçekleştirmeyi hedeflemektedir. Orta Asya'dan Avrupa'ya kadar uzanan bölgede güvenliğin sağlanması bu stratejinin bir gereğidir. Küresel güç olma yolunda attığı adımları Batıya doğru Orta Asya devletleri ile birlikte atmaktadır. Çin'in asıl amacı, kuzeybatı bölgesinde güvenli ortamın 
oluşturulması ve böylece bütün gücünü Pasifik bölgesine yöneltme stratejisini gerçekleştirme isteğidir. Bundan dolayı Hazar Havzası ve çevresinin güvenliğini sağlamak ve bölgede aktif bir şekilde rol alabilmek için bölgesel ve küresel örgütlerle varlığını hissettirmek istemektedir (Aydın, 2005: 75). Pekin hükümetini bölge ile yakından ilgilendirmeye iten asıl neden Orta Asya'da siyasal ve ekonomik konularda yaşanan gelişmelerin Çin sınırları içinde yaşayan Uygur Türklerini ve Orta Asya'daki azınlıkları harekete geçirme ihtimalinin dolaylı olarak Çin'i etkileyecek olmasıdır. Bu yüzden Çin, bölgedeki güvenli ortamın sağlanmasına önem vermektedir (Telatar, 2005: 180).

Rusya'nın bu bölgeye bakışı ise tamamen stratejiktir. Burada bulunan enerji kaynaklarına aslında ihtiyaç duymamaktadır. Bu bölgedeki enerji kaynaklarında söz sahibi olarak Batıya gönderilen petrol ve doğalgazda önemli bir konumda yer almak istemektedir (Olson, 2002). Bölge ülkelerini kontrol altına alarak enerji boru hatlarını kendi sınırlarından geçirmek isteyen Rusya, böylece enerji ihtiyacı duyan devletleri kendine bağımlı hale getirecektir (Gazigil, 2006: 101). Rusya'nın etkisi Orta Asya ülkelerinin ekonomisini oldukça büyük oranda etkilemektedir. Orta Asya devletleri küresel pazarlara açılmış olsalar da Rus sermayesi bu ülkelerin pazarlarında önemli bir yere sahiptir. Rusya'nın bu ülkeler üzerindeki yatırımları daha çok gaz sanayi ve hidroelektrik santralleri üzerine yoğunlaşmıştır (Jafalian, 2003: 55). Rusya'nın bölgeye enerji yatırımları odaklı yeni ekonomik yaklaşımının ilk büyük adımını üç büyük enerji şirketi Lukoil, Yukos ve Gazprom'un birleşerek 25 Temmuz 2000 tarihinde ortak Hazar Petrol Şirketini kurmaları oluşturmuş̧ur (Purtaş, 2006: 169-170). Ayrica Rusya yeni boru hatlarının yapılmasına engel olarak Sovyetler zamanından kalan ve kendi sınırlarından geçen eski güzergâhların kullanılmasının avantajlarını da kullanmaktadır (Kamalov, 2011: 44).

Rusya, Hazar'daki ülkelerde etkili olabilmek için petrol şirketlerine nüfus etmeyi planlamış ve bu doğrultuda Azerbaycan petrol şirketlerine ortak olmuştur. Buna benzer anlaşmalar Türkmenistan ve Kazakistan ile de imzalanmıştır (Purtaş, 2006: 170). Rusya geliştirdiği politikalar çerçevesinde Hazar enerji kaynaklarında söz sahibi olmaya çalışmış ve yapılan ticaretle önemli bir konum elde etmiştir. Ayrıca Rusya'nın kendi gücünü pekiştirmek ve sürekliliğini sağlama yolunda bölgedeki güvenliği tehdit eden unsurları yeri geldiğinde kendi lehine olacak şekilde desteklemiş, bir bakıma \%100 güvenlik anlayışıyla hareket etmemiştir.

Avrupa Birliği’ne gelecek olursak, 11 Eylül olaylarına kadar birliğin pek ilgili olmadığı bir bölge olan Orta Asya'ya, ABD'nin Afganistan'a Özgürlük Operasyonu ile müdahale etmesi ve AB'nin de yanında yer almasıyla Orta Asya, uluslararası politikada önemli bir konuma gelmiş ve güvenlik politikaları kapsamında AB'nin ilgi alanına girmiştir (Özalp, 2011). 2007 yılında $\mathrm{AB}$, Orta Asya için önemli adımlar atarak Avrupa'nın güvenlik ve istikrar alanının genişletilmesi kapsamında bölgeye yönelik hedefler ortaya koymuştur. Bu kapsamda özellikle Orta Asya ülkeleri, Karadeniz bölgesi ve Rusya ile ilişkilere dikkat edilmesi gerektiği üzerinde durulmuştur (Hatipoğlu, 2008).

AB'nin Hazar'a yönelik politikaları ekonomik amaçlıdır. $\mathrm{Bu}$ nedenle çeşitli projeler geliştirilmiştir. Bunlardan biri TACIS - Bağımsız Devletler Topluluğuna Teknik Yardım programıdır. Amaç, bölge ülkelerinin Pazar ekonomisine geçmesi ve demokratikleşmesi şeklinde sıralanabilir (Karluk, 2008). Diğer bir proje ise TRACECA - Avrupa, Kafkasya, Asya Taşıma Koridoru programıdır. Amacı, Kafkasya, Orta Asya ve Karadeniz'de uluslararası ulaşımı geliştirmeyi, siyasi ve ekonomik ilerlemeyi hedeflemektedir (Şensoy, 2007). TRACECA projesinin en önemli araçlarından biri “Avrupa'ya Devletlerarası Petrol ve Gaz Nakli - INOGATE programıdır. INOGATE, bölge devletleri arasında enerji 
konusunda bölgesel işbirliğini güçlendirmek amaçlı oluşturulmuştur. Böylelikle yeni boru hatlarının inşası sağlanacak ve kaynakların Avrupa'ya güvenli bir şekilde taşınmasında bölgesel güzergâhlar oluşturulacaktır (Ayhan, 2009).

Avrupa Birliği'nin günümüzde ihtiyaç duyduğu petrol ve gazın büyük bir kısmını Rusya karşılamaktadır. Fakat Rusya ile olan münasebetlerden ötürü gelen enerjinin sürekliliği ve devamlılı̆̆ında sıkıntılar yaşanmaktadır. Bu unsurların herhangi birinin sağlanamaması AB'yi yeni arayışlara itmiştir. Hazar'da bulunan enerji rezervleri Orta Doğu ile karşılaştırıldığında az fakat Kuzey Denizindekine oranla daha fazladır. Ayrıca araştırmaların tam yapılmamış olması bu bölgedeki potansiyel kaynakların gün yüzüne çıkmadığının bir göstergesi olarak nitelendirilmektedir. Bu yüzden $\mathrm{AB}$ 'nin bu bölgeye ilgisi oldukça artmıştır. $\mathrm{Bu}$ ilgi beraberinde yeni fikir ve projeleri de ortaya çıkarmıştır. En önemli husus, AB'yi Rusya'ya bağımlı kalmadan yeni alternatif enerji kaynakları ve enerji nakil hatları oluşturmaktır. Bu doğrultuda çeşitli projeler geliştirilmiştir. Fakat bu tarz plan ve projelerin hayata geçirilmesinde AB'yi endişelendiren bazı unsurlar vardır. Bunların en başında güvenlik gelmektedir. Enerjinin güvenli bir şekilde çıkarılmasının yanı sıra güvenli bir şekilde nakli de oldukça önemlidir. Bu kapsamda bölgedeki terör ve istikrar sorunları ilk başta ortadan kaldırılması gereken problemlerdir.

Güvenlik açısından AB'yi değerlendirecek olursak, Orta Asya'da önemli bir güç olma özelliği göstermemektedir. Çünkü bölge askeri olarak Rusya ve ABD'nin kontrolü altındadır. $A B$, bölge için daha çok sivil güvenlik projeleri üzerine çalışmaktadır. Fakat bu çalışmalar bölge ülkeleri için pek etkili olmamıştır. AB'nin etkili olabilmesi için bölgede askeri olarak yer alması gerekmektedir. Ancak bu AB'nin dış politikada sivil güç olma planlarına ters düşmektedir (Saygın ve Çelik, 2011: 92). Avrupa Birliği, Orta Asya'da çatışma ve kriz önleyici programlarla istikrarın korunması için uzun soluklu planlar yapan tek uluslararası aktördür. AB stratejisi çok kapsamlı bir ulus inşası planı içermektedir. Fakat AB'nin bölge için ayırdığı finansal kaynak yeterli olmadığı gibi bölge ülkelerinin işbirliği konusunda isteksiz davranmaları bu stratejileri olumsuz etkilemiştir.

Türkiye, Sovyetler Birliği'nin dağılmasıyla birlikte bölgeye hem coğrafi hem de kültürel yakınlık duymasından dolayı yüzünü buraya çevirmiş ve bu bölgedeki güç boşluğunu doldurma girişimi içerisine girmiştir. Rusya'nın bölgede tekrar güçlü hale gelmesini ve İran'daki radikal İslam'ın bu bölgeye yayılmasını istemeyen Batı, bu yaklaşımıyla bölgede aktör devlet olarak Türkiye'yi desteklemiştir. Fakat SSCB'nin yıkılması gibi beklenmeyen büyük bir olay karşısında Türkiye'nin hem plan, proje hem de ekonomik olarak hazırlıksız yakalanması, bölgede yeterince etkili olamamasına neden olmuştur.

Soğuk Savaş sonrası yeni dünya düzeninin merkezini oluşturan Hazar bölgesinde Türkiye'nin oynayacağı hayati rol için uygulanabilir yeni dış politikası şu temeller üzerine oturtulmalıdır. Hazar Havzası'nda bulunan bol miktarda petrol ve doğalgaz kaynaklarının uluslararası pazarlara Türkiye üzerinden çıkarılmasını ve Türkiye'nin enerji ihtiyacını güvenli ve kesintisiz bir şekilde karşılarken ülkenin stratejik öneminin arttırılmasını sağlamak. Asya ile Avrupa arasındaki Doğu-Batı ilişkilerinde bir köprü görevi görerek pazar coğrafyasındaki Türk cumhuriyetlerinin enerji kaynaklarının Rusya dışı güzergâhlarla ihracını sağlayarak bu ülkelerin ekonomik açıdan bağımsızlıklarının geliştirilmesine yardımcı olmak. Türkiye'nin İpek Yolu bölgesindeki ülkelere yönelik geçmişten kaynaklanan yakınlık ile kültürden ekonomiye kadar birçok alanda ilişkilerini geliştirerek Türk hinterlandını yaratması gerekmektedir (Davutoğlu, 2004: 181).

Bölgedeki petrol ve doğalgazın üretimi, taşınması ve pazarlanması başta Türkiye olmak üzere dünya genelindeki birçok ülkeyi etkilemektedir. Petrol ve doğalgaz bakımından son 
derece kıt kaynaklara sahip olan Türkiye'nin, söz konusu kaynaklara yakın bir coğrafyada bulunması enerji temininde büyük avantajlar sağlamaktadır. Bu avantajlardan yararlanarak uzun vadeli planlar ile hızlı ve dengeli bir ekonomik büyüme sağlayabilecek, artan ve hızla artacağı tahmin edilen enerji ihtiyacını gerektiği biçimde karşılayacak çözümleri ve politikaları üretmek zorundadır.

Bölge devletlerinin çoğunluğunun Türk kökenli olması ve aynı dini benimsemeleri Türkiye'nin birçok plan ve projesini geliştirmesinde ve elde etmesinde işini kolaylaştıracak hususlar olarak görülmektedir. Bu bölgeye yönelik politikalar belirlenirken öncelikle bölgede tarihi geçmişten gelen bir etkisi olan Rusya ile çatışmamaya özen gösterilmeli, Rusya ile birlikte ortak politikaların oluşturulması hedeflenmelidir. Bu gelişmeler içinde Türk kimliği ve büyük Türk dünyası gibi söylemler yerine ekonomik değerler, karş1lıklı kalkınma ve karşılıklı işbirliği gibi olgular ön plana çıkarılmalıdır.

Türkiye, Hazar Havzası'na yönelik uyguladığı bazı politikalarda ABD ile birlikte hareket etmiş ve bunun sonucunda özellikle Rusya ve İran'1n tepkisini çekmiştir (Ekici, 2015: 335). Bu nedenle Türkiye, bölgeye yönelik uyguladığı politikalarda bölgenin önemli aktörleri olan Rusya ve İran ile karşılıklı iyi ilişkiler kurmaya özen göstermelidir. Çünkü ABD’nin aksine Türkiye bölge devletidir. Bundan dolayı komşularıyla beraber iyi geçinmek zorundadır. Başta Rusya olmak üzere İran ile ekonomik ilişkileri ve çıkarları vardır. Bu nedenle Türkiye bölgede etkisini azaltmamalı, fakat Rusya'yı ve İran'ı da dışlayacak politikalardan uzak durmalidir.

Türkiye'nin bölge ülkeleri ile olan ilişkilerinde gözden kaçırdığı en önemli husus, bu devletlerin artık her birinin ayrı birer bağımsız devlet oldukları gerçeğidir. Türkiye, genelde bölge ülkelerini bütüncül bir yaklaşımla ele almış, her biri için ayrı ayrı stratejiler geliştirilmemiştir (Birsel, 2007). Oysaki Hazar petrol ve doğalgaz projelerinde ve bunların tüketim bölgelerine ulaştırılmasında özellikle Azerbaycan, Türkmenistan ve Kazakistan bir bakıma birbirlerine rakip devletlerdir. Türkiye'nin Hazar Havzası enerji kaynaklarına yönelik bölgedeki Türk cumhuriyetleri ile ilişkilerinde Azerbaycan'la ilişkilerini geliştirirken Türkmenistan'1 ihmal etmiştir. Rusya ile olan yakın ilişkileri nedeniyle Kazakistan ile yeterince ilişki kuramamıştır. $\mathrm{Bu}$ gibi nedenler bölgeye yönelik yürüttüğü enerji politikalarının temel eksikliklerini oluşturmaktadır.

Hazar Havzası'ndaki enerji kaynaklarının uluslararası pazarlara açılmasında son yıllarda rol almaya başlayan Türkiye açısından da bölgenin önemi her geçen gün daha da artmaktadır. Türkiye, BTC petrol boru hatt1 ve BTE doğalgaz boru hattı ile Hazar bölgesindeki enerji kaynaklarının aktif bir şekilde kullanımını sağlamaktadır. Ayrıca Türkiye 2015 yılında temeli atılan Güney Gaz Koridoru kapsamındaki Trans Anadolu Doğalgaz Boru Hattı projesi ile birlikte Hazar bölgesindeki rezervlerin uluslararası pazarlara transferini sağlayan merkez ülke konumunu elde edecektir. TANAP, küresel enerji piyasalarını açılmak isteyen diğer Hazar bölgesi ülkelerinin de ilgisini çekerken bu durum enerji ithalatında ülke çeşitliliğini sağlamak isteyen Türkiye'ye ciddi firsatlar sunmaktadır.

İran ise hemen başucunda yeni kurulan cumhuriyetlere karşı ekonomik ve ticari ilişkileri ilk sıraya koyan bir yaklaşım içinde olmuştur. İran, kendisini bu dönemde Orta Asya enerji kaynaklarının dünyaya açılması için doğal bir enerji güzergâhı olarak görmektedir. SSCB'nin dağılmasından sonra Hazar'ın hukuki statüsüyle ilgili çıkan sorunlar İran'ın Hazar enerji kaynaklarına yönelik politikalarında çelişkiler yaşamasına sebep olmaktadır. İlk başlarda Rusya'nın da taraf olduğu ortak paylaşım sisteminin ilerleyen zamanlarda Moskova yönetimi tarafından Kazakistan ve Azerbaycan ile sektörel paylaşım anlaşmaları imzalamasıyla sona ermesi, İran'1, bölgede ortak paylaşım sistemi benimsemesinde tek 
destekçisi Türkmenistan ile yalnız bırakmıştır. İran, aslında Hazar'daki hukuki statüsü tartışmalarında kendisine \%20'lik bir pay düşmesi halinde Hazar için planlanan sektörel bölünmeyi kabul edeceğini açıklamıştır. Fakat sektörel paylaşım sonucunda istediği paydan daha az paya sahip olacağı için bu paylaşımı reddetmiştir. Bu problem, İran'ın Azerbaycan kara sularını ve hava sahasını ihlal etmesine neden olmuş ve tehlikeli durumların yaşanmasına sebebiyet verdiğinden dolayı Azerbaycan ve Türkiye arasında yakınlaşma meydana gelmiştir. İran ayrıca Kazakistan ve Türkmenistan'ın sahip olduğu petrol ve doğalgazın uluslararası pazarlara taşınması için oluşturulan boru hatlarıyla da yakından ilgilenmektedir. İran'a karşı olan ABD, Tahran yönetiminin planlarını daima engellemektedir. Bölgedeki enerji kaynaklarının uluslararası pazarlara taşınması konusunda ABD, Rusya ve İran arasında ciddi bir görüş ayrılıkları bulunmaktadır. Bölgedeki ABD-İran çekişmesi, enerji kaynakları üzerindeki stratejileri direk etkilemektedir. Ayrıca Washington yönetimi, İran'ı her türlü dışarıda bırakacak enerji nakil hatları üzerinde durmaktadır (Kleveman, 2004: 134).

Günümüzde İngiltere ile İran arasındaki siyasi ilişkilerin iyileşme süreci dikkate alındığında, pek fazla dile getirilmese de, ABD dâhil Batı'nın İran'a yönelik tutumunda yakın bir zamanda önemli değişikliklerin görülebileceği dikkatlerden kaçmamaktadır. Bu da, Hazar petrolleri için her an yeni bir güzergâhın oluşturulabileceği anlamına gelmektedir. İran, 11 Eylül sonrası ABD'nin bölgeye yerleşmesi ve Rus dış politikasında hedefin ABD'ye doğru kaymasıyla birlikte yeni bir tehdit algılamasının içerisine girmiştir. Bu kapsamda, İran'ın Hazar bölgesine yönelik stratejileri; bölge ülkeleriyle iyi ilişkiler kurarak, ABD'nin çevreleme politikasından ve uluslararası siyasal yalnızlıktan kurtulmak, komşularının istikrarı açısından da önem arz eden kendi sınırlarının güvenliğini korumak, özellikle Türkmenistan ve Kazakistan'la ticari ve ekonomik ilişkileri geliştirmektir. Ayrıca Rusya ve Türkiye ile ilişkilerini seviyeli bir şekilde geliştirmek ve kendi ekonomik etkisini ve gelişimini engelleyen ABD politikalarını ortadan kaldırmak stratejik planları arasında yer almaktadır. Uluslararası işbirliğini arttırmak için $\mathrm{AB}$, Çin ve Japonya ile ilişkilerini güçlendirmekte başlıca hedeflerindendir. Önümüzdeki süreçte İran'ın Hazar enerji kaynaklarına yönelik politikalarında etkinliğini artıracağı düşünülmektedir. Olaylara mesafeli davranan Çin'in tavırları da İran'ın bölgeye yönelik girişimlerinin devamı açısından belirleyici bir etkendir. Ayrıca ABD, İran'a yönelik ambargosunu yumuşatır ve Hazar enerji kaynaklarının İran üzerinden uluslararası pazarlara ulaşmasına izin verirse, İran bölgede enerji alanında çok önemli bir faktör haline gelecektir.

\section{Sonuç ve Öneriler}

Günümüzde güvenlik kavramı yaklaşımı ile ekonomik değerler ve enerji kaynaklarının yoğun olduğu bölgelerdeki güvenliğin ve sürdürülebilirliğinin sağlanması gerekmektedir. Bundan dolayı Hazar'ın sahip olduğu enerji kaynakları konusunda ve bu kaynakların paylaşılması yönündeki meselenin, enerji güvenliği ve enerji politikaları açısından küresel ve bölgesel bir önem taşıdığı ifade edilebilir.

1991 yılında Sovyetler Birliği'nin dağılmasıyla birlikte Hazar'a kıyısı olan devlet sayısının artması sonucu buradaki petrol ve doğalgazın kullanımında büyük tartışmalar başlamıştır. İlk 1993 yılında Hazar'ın statüsündeki boşluk dile getirilmiş ve 2018 yılına kadar ciddi adımlar atılamamıştır. Hâlbuki Hazar'daki sorun buranın deniz veya göl olup olmamasından ziyade buradaki kaynaklarının ne şekilde paylaşılacağından kaynaklanmaktadır. 12 Ağustos 2018 tarihinde yapılan anlaşma da gösteriyor ki Hazar’a deniz veya göl statüsünün verilmesinden ziyada paylaşım konusu daha mühim ve karmaşıktır. Anlaşma metninde Hazar, deniz olarak nitelendirilmesine rağmen paylaşım konusunda hem deniz hem de göl unsurları dikkate alınarak bir mutabakata varılmak istenmiştir. Bu da Hazar'ın kendine özgü bir su havzası 
olduğunun göstergesidir. Statü sorunu çözülmüş gibi görünse de anlaşma maddelerinden de anlaşıldığı gibi asıl mesele olan deniz tabanının paylaşımı taraflar arasında yapılacak karşılıklı anlaşmalara bırakılmıştır. $\mathrm{Bu}$ da, bir bakıma paylaşım sorununun devam ettiğini açıkça göstermektedir.

Bölgedeki enerji güvenliğini tehdit eden en önemli sorunlardan biri de ayrllıkçı hareketlenmelerdir. Başta Azerbaycan-Ermenistan arasındaki Dağlık Karabağ sorunu bölgede yapılacak enerji projelerinin güzergâhını olumsuz etkilemektedir. Bununla birlikte bölge ülkelerinde yaşanan ekonomik istikrarsızlık ve bağımsızlık mücadeleleri bölgede uzun vadeli projelerin gerçekleşmesine engel olmaktadır. İran ile Azerbaycan arasında yaşanan siyasi sorunlar da bölge güvenliğini tehdit etmektedir. Bunun yanı sıran Azerbaycan'ın ekonomik gelişmişliğinin artması İran'ın toprak bütünlügünü tehlikeye atmaktadır. İran'da bulunan Azeri nüfusunda bağımsızlık ve ayrılıkçı sözlemlerin çıkmış olması İran'1 endişelendirmektedir. $\mathrm{Bu}$ da iki ülkenin birbirlerine karşı sürekli endişeli tutum sergilemesine neden olmaktadır.

Rusya bölge dengelerini koruyabilmek için var olan sorunları kendi lehine destekleyerek kontrol altında tutmakta ve böylelikle gerçekleştirilecek girişimlerde elini kuvvetlendirmektedir. Rusya aynı zamanda Hazar'a giriş ve çıkışları kontrol altında tutabilmek için deniz statüsüne sonuna kadar karşı çıkmaktadır.

Hazar Havzası'ndaki enerji kaynakları ve enerji nakil hatlarının güvenliğinin sağlanması gerekmektedir. Bu amaçla,

-İlk olarak enerji arz güvenliği için Hazar Havzası'nın hukuki statüsünün netleştirilmesi gerekmektedir ve bu, 12 Ağustos 2018 tarihinde Kazakistan'ın Aktau şehrinde yapılan zirve ile gerçekleştirilmiştir. Yapılan anlaşmada Hazar, "deniz" olarak nitelendirilmiş, fakat paylaşım konusunda 1982 BMDHS'nin dışında tutulması ve deniz tabanının paylaşımının taraflar arasında yapılacak anlaşmalara bırakılması, statünün belirlenmesinin yeterli olmadığını göstermiştir.

- Hazar'da bugüne kadar en büyük problem hukuki statüsünün belirlenememiş olması ve bu doğrultuda paylaşımın yapılamamasıdır. Ancak yapılan anlaşmada gösteriyor ki Hazar'a hukuki statü kazandırmak problemleri çözmeyecek, ta ki belirlenen statünün hukuki normları uygulanarak bu problem ortadan kaldırılana kadar.

- Hazar, ne kadar anlaşmada "deniz" olarak nitelendirilmiş olsa dahi uygulama alanında Hazar'ın hem deniz hem de göl olarak dikkate alındığı göze çarpmaktadır. Bu da bölge ülkeleri ve var olan enerjinin güvenliği için hassas nokta olan paylaşım konusuna bir netlik kazandırmadığı gibi bu paylaşımın ilerleyen zamanlarda taraflar arasında karşılıklı yapılmasını öngörmüştür. Dolayısıyla belirsizlik ortamı tamamen ortadan kaldırılamamıştır.

Belirsizlik ortamının sona ermesiyle alternatif enerji kaynakları arayan devletlerin bölgeye olan yaklaşımları daha da güçlenecektir. Bu yaklaşım, Asya'dan Avrupa'ya kurulacak olan enerji koridoru için önemli bir unsurdur.

- Avrasya'nın kalbinde yer alan bu bölge Doğu-Batı koridorunda doğal bir geçiş noktası olma özelliğine sahip olmakla birlikte, bunun bir avantaj haline gelebilmesi için güvenilir enerji koridorlarının oluşturulması gerekmektedir.

- Ülkelerin toprak bütünlüğünün, enerjinin ve nakil hatlarının korunması ve istikrar ortamının sağlanması amaciyla uluslararası işbirliğinin küresel ve bölgesel ölçekte arttır1mas1 gerekmektedir. 
- Stratejik kaynakların azalması, bu kaynakların tehdit altında bulunması 21. yüzyılda Hazar Havzası'nda ortak girişimleri ve işbirliğini zorunlu kılmaktadır. Bu gelişmelerden dolayı güvenliğin ve istikrarın geliştirilmesi, yeni güvenlik anlayışlarının belirlenmesi, yaygınlaştırılması ve güvenlik ile ilgili yeni yönelimlerin ortaya çıarılması gerekmektedir.

- Hazar Havzası'nda uluslararası işbirliği arttırılmalı, ortaklığa, diyaloğa ve yumuşak güce dayalı güvenlik anlayışı benimsenmelidir.

- Bölgedeki petrol ve doğalgaz kaynaklarının dünya enerji arzı yönünden değerlendirilmesi, enerji nakil hatlarının ve bu hatların güvenliğinin dünya enerji arzı ve küresel güvenlik boyutu açısından incelenmesi gerekmektedir.

- Etnik yapıların bölgesel ve küresel güvenliğe etkileri, güvenliğin sosyal ve kültürel boyutundaki yansımaları dikkate alınmalıdır.

- Bölgesel anlamda enerji kaynakları ve çatışma, enerji ve milli güvenlik, enerji arz ve nakil güvenliği, enerji ve çevre güvenliği konuları incelenmeli ve irdelenmelidir.

- Hazar Havzası ile ilgili enerji bağımlılığı ve bunun dış politikaya etkileri, enerji arz eden ülkelerin dış politikaları, enerji ile ilgili uluslararası kuruluşların yapıları ve politikaları, uluslararası enerji stratejileri, enerji arz eden şirketlerin stratejileri ve bunların uluslararası ilişkilere etkileri dikkatle incelenmelidir.

Bütün bu bilgiler ışığında Hazar Havzası, bölge ve dünya barışına, enerji alanında işbirliğine katkı sağlayabileceğinden dolayı Kuzey-Güney ve Doğu-Batı eksenli önemli ve belirleyici bir koridor haline getirilmelidir. Hazar'da sağlanacak düzenli bir rejim, en başta Türkiye olmak üzere bölge ülkelerinin çıkarlarına hizmet edecektir. Hazar'ın jeopolitik ve jeostratejik önemi Avrasya'da her zaman belirleyici bir faktör olacak, ayrıca etkin ve verimli bir şekilde değerlendirilmesi bölgesel ve uluslararası ekonomiye oldukça önemli katkılar sağlayarak, bölgedeki istikrar ortamına destek verebilecektir. 


\section{KAYNAKÇA}

Anadolu Ajans1 (2018). https://www.aa.com.tr/tr/info/infografik/11156

AYDIN, M. (2005). Çin'in Stratejik Hesaplarında Orta Asya. M. Aydın (Ed.). Küresel Politikada Orta Asya içinde. Ankara: Nobel Yayınları.

AYHAN, V. (2009). Avrupa'nın Enerji Arz Güvenliğinde Türkiye: Petrol, Doğal Gaz ve Entegrasyon. Uluslararası Illişkiler. Cilt: 5, Sayı: 20, s. 155-178.

BİLGící, M. (2005). Hazar Enerji Havzası'nın Türkiye ve Çevre Ülkeler Açısından Stratejik Önemi. Yayımlanmamış Yüksek Lisans Tezi. Gebze: Gebze Yüksek Teknoloji Enstitüsü Sosyal Bilimler Enstitüsü.

BİRSEL, H. (2006). Eski Dünyanın Karanlık Yüzü Orta Asya Jeopolitiği. İstanbul: IQ Kültür Sanat Yayıncilık, s. 78.

BİRSEL, H. (2007). Yeni Dünya Hakimiyet Ekseni: Türkiye-Güney Kafkasya. 2023. Sayı: $76, \mathrm{~s} 37$.

BP Statistical Review of World Energy, (2016). https://www.bp.com/content/dam/bp/pdf/energy-economics/statistical-review2016/bp-statistical-review-of-world-energy-2016-full-report.pdf

BRZEZİNSKİ, Z. (2005). Büyük Satranç Tahtası. Y. Türedi (Çev.). İstanbul: İnkılap Yayınevi. s. 14.

CİCIOĞLU, F.. SARAN, M. BABAKUŞ, S. (2012). Abhazya Cumhuriyeti'nin Yasal Statüsünün Uluslararası Hukuk Açısından Değerlendirilmesi. H. Çomak, A. Ercan, B. Ercan (Ed.). Uluslararası Kafkasya Kongresi. Kocaeli: Kocaeli Üniversitesi Yayınları.

ÇELIKPALA, M (2014). Enerji Güvenliği: NATO'nun Yeni Tehdit Algısı. Uluslararası İlişkiler. Cilt 10, Say1 40, s. 75-99.

DAVUTOĞLU, A. (2004). Stratejik Derinlik. İstanbul: Küre Yayınları.

DEDEOĞLU, B. (2003). Yeniden Yapılanan Dünya Sistemi Çelişkileri, Çelişkiler Sistemi. 2023. s. 40.

DEMIR, S. (2015). NATO'nun Enerji Güvenliği Politikaları. H. Çomak, C. Sancaktar, Z. Yıldırım (Ed.). Enerji Diplomasisi içinde. İstanbul: BETA, s. 143-162.

DEVLET, N. (2006). Enerji Hatlarının Güvenliğinde Ülkelerin İstikrar Sorunları. W. Gumpel, A. Alpay (Ed.). Avrupa ve Orta Asya Arasındaki Enerji Köprüsü Türkiye içinde. Konrad-Adenauer-Stiftung Yayını. s. 93-109.

EFEGilL, E. (2000). Washington'un Hazar Havzası Politikası ve Türkiye. Avrasya Dosyası. 6.2 .

EKİCI, K. D. (2015). Enerji Diplomasisi ve Hazar Havzası. H. Çomak, C. Sancaktar, Z. Yıldırım (Ed.). Enerji Diplomasisi içinde. İstanbul: BETA. s. 333-345.

GAZIGiL, O. (2006). Rusya'da Avrasyacıllk Düşüncesi ve Yeni Alternatif Arayışları. İ. Çomak (Ed.). Rusya Stratejik Araştırmalart-1 içinde. İstanbul: TASAM Yayınları.

GÜNDÜZHEV, A. (2013). Rusya Federasyonu'nun Kafkasya Politikaları ve Bölge Enerji Güvenliği. Yayımlanmamış Yüksek Lisans Tezi. Kocaeli: Kocaeli Üniversitesi Sosyal Bilimler Enstitüsü.

GÜRPINAR, B. B. ve Kesici, A. (2005). Clinton'dan Bush'a ABD'nin Hazar Enerji Politikası. I.U. Siyasal Bilgiler Fakültesi Dergisi. No: 33, s. 165.

HATİPOĞLU, E. (2008). Avrupa Birliği-Orta Asya İlişkilerinde Yeni Bir Stratejiye Doğru (mu?). OAKA. Cilt: 3, Say1: 5.

JAFALIAN, A. (2003). Russia, "The United States And Central Asia: The New Version Of The Great Game", French Strategial Military Yearbook, 2002-2003.

JANSEN, J.C. ve M.G. Boots (2004). "Designing Indicators of Long-term Energy Supply Security", ftp://ecn.nl/pub/www/library/report/2004/c04007.pdf 
KAMALOV, İ. (2011). Rusya'nın Orta Asya Politikalart. Ankara: Hoca Ahmet Yesevi Uluslararası Türk-Kazak Üniversitesi Raporu.

KANTARCI, H. (2006). Kıskaçtaki Bölge Kafkasya. İstanbul: IQ Kültür Sanat Yayıncılık.

KARLUK, S.R. (2008). Küreselleşen Dünya'da Avrupa Birliği'nin Orta Asya Ülkeleri İle Olan Ilişkileri ve Bölgeye Yönelik Stratejisi. http://www.bilgesam.org/Images/Dokumanlar/0-2632014070721 sosbilkongre50.pdf (01.05.2016).

KASIM, K. (2006). Rusya-Ermenistan İlişkileri: Bölgesel Hegemon Güç İle Stratejik Ortağ1 Arasındaki İlişki. İ. Çomak. (Der.). Rusya Stratejik Araştırmalar-1 içinde. İstanbul: TASAM Yayınları. s. 243.

KLEVEMAN, L. (2004). Yeni Büyük Oyun. H. Güldü (Çev.). İstanbul: Everest Yayınları.

KOÇGÜNDÜZ, L. M. (2010). Hazar Bölgesi Enerji Politikaları. K. İnat, B. Duran, M. Ataman (Ed.). Dünya Çatışmaları 1. Cilt içinde. Ankara: Nobel Yayın Dağıtım. s. 487.

KRUYT, B. (2009). Indicators for Energy Security. http://www.sciencedirect.com/science/article/pii/S0301421509000883

KÜLEBİ, A. (2007). Yeni Dengeler Açığa Çıkıyor. Strateji. Cilt: 3, No: 139, s. 10.

MERT, O. (2004). Türkiye'nin Kafkasya Politikası ve Gürcistan. İstanbul: IQ Kültür Sanat Yayıncilik.

MEULEN, Evert Faber Van Der (2009). "Gas Supply and EU-Russia Relations", EuropeAsia Studies, http://www.tandfonline.com/doi/abs/10.1080/09668130902905040

NOGAYEVA, A. (2007). Hazar'da Petrol Dans1. Strateji. Cilt: 3, No: 155, s. 20.

NOGAYEVA, A. (2011). Orta Asya'da ABD, Rusya ve Çin Stratejik Denge Arayışları, 1. Baskı, Karınca Yayınları, Ankara.

OĞAN, G. (2007). Orta Asya Enerji Diplomasisi Hiz Kesmiyor. Stratejik Analiz. No: 86, s. 8.

OLSON, R. (2002) "Turkey - Iran Relations, 2000 - 2001: The Caspian, Azerbaijann and the Kurds", Middle East Policy, Vol.IX, No.2, June 2002, 111 - 129.

ÖZALP, O. N. (2011). Avrupa Birliği'nin Orta Asya Politikası. Civil Academy.

PALA, C. (2003). 21. Yüzyıl Dünya Enerji Dengesinde Petrol ve Gazın Yeri ve Önemi: Hazar Hatlarının Kesişme Noktası Türkiye. Avrasya Dosyası-Enerji Özel. Cilt: 9, No: 1 , s. 17.

PALA, C. (2007). 20. Yüzyılın Şeytan Üçgeni: ABD-Petrol-Dolar Krizlerinin Perde Arkası. İstanbul: Yasak Elma Yayınları. 2. Bask1. s. 207.

PURTAŞ, F. (2006). Rusya'nın Orta Asya'ya Yeniden Dönüşü. İ. Çomak (Ed.). Rusya Stratejik Araştırmalarl-1 içinde. İstanbul: TASAM Yayınları.

SAYGIN, H. ve ÇELİK, C. (2011). Jeo-Enerjik Bakış. İstanbul: İstanbul Aydın Üniversitesi.

SEVIM, C. (2012). Küresel Enerji Jeopolitiği ve Enerji Güvenliği. Journal of Yaşar University. 26(7), s. $4378-4391$.

SOMUNCUOĞLU, A. (2006). Orta Asya Enerji Oyununda Asya Devleri. 2023. Sayı: 66, s. 39.

SOLİGO, R. ve AMY J. (1999). "China's growing energy dependence: the costs and policy implications of supply alternatives." The James A. Baker III Institute for Public Policy, Rice University, Houston, Texas (1999).

St. Petersburg Bildirisi, (2006). http://www.g8.utoronto.ca/summit/2006stpetersburg/energy.html\#plan

ŞENSOY, S. (2007). Demirden Ipek Yolu: Traceca Projesi. http://www.tasam.org /trTR/Icerik/24/demirden_ipek_yolu_traceca_projesi (01.05.2016). 
TANRISEVER, O. (2001). Moskova'nın Çeçenistan Çıkmazı ve Çıkış Arayışları. Avrasya Dosyası. Ankara: ASAM Yayınları. Cilt: 6, Sayı: 4, s. 180-201.

TELATAR, G. (2005). Şangay İşbirliği Örgütü: 21. Yüzyılın Bölgesel/Global Çekim Merkezi. A. Sandıklı, İ. Güllü (Ed.). Geleceğin Süper Gücü Çin içinde. İstanbul: TASAM Yayınları.

TURAN, A. P. (2010). Hazar Havzası'nda Enerji Diplomasisi. Bilge Strateji. Cilt: 2. Sayı: 2. ÜNAL, B. (2015). Iran Nükleer Anlaşması ve Türkiye'ye Etkileri. http://www.bilgesam.org/Images/Dokumanlar/0-7420150723211232 .pdf (22.04.2016).

YILMAZ, S. (2009). Enerji Güvenliği. http://ees2.beykent.edu.tr/WebProjects /Uploads/yilmaz-haziran.pdf. (10.03.2016).

YÜCE, Ç. K. (2007). Avrasya'da Yaşanan Enerji Savaşları Sürecinde Türkiye'nin Siyaseti Ne Olmalı?. 2023. Sayı: 77, s. 44. 